\begin{tabular}{|c|c|c|}
\hline $\mathrm{S}$ & $\begin{array}{c}\text { Proceeding } \\
\text { International Conference on Islamic Educational Guidance and Counseling } \\
\text { 9 December 2021 } \\
\text { E-ISSN: } 2827-9581 \\
\text { Website: http://conference.iainsalatiga.ac.id/index.php/iciegc }\end{array}$ & $\begin{array}{l}\text { Plete } \\
\text { Hal. } 115-128\end{array}$ \\
\hline
\end{tabular}

\title{
PERAN KONSELING KELUARGA DALAM MENGATASI PERMASALAHAN KELUARGA
}

\author{
Rosmala Dewi $^{1}$, Andis Azizah ${ }^{2}$, Susi Mareska ${ }^{3}$, Suriyanti ${ }^{4}$, Hartini $^{5}$ \\ 1,2,3,4,5 IAIN Curup
}

\begin{tabular}{l}
\hline \hline Informasi Artikel \\
\hline Penulis Korespondensi: \\
Rosmala Dewi \\
Email: \\
dewirosmala13@gmail.com
\end{tabular}

\begin{abstract}
In essence, the family is a container that shapes and influences children's attitudes and character. In forming a harmonious family and able to carry out their responsibilities as a family is not an easy thing, many families are unable to carry out their functions properly. The inability of the family in fostering harmonious relationships will be able to trigger problems in the family. Therefore, counseling provides a solution, namely the existence of a counseling service that is family in nature in finding and creating harmonious and balanced psychological conditions. Family counseling aims to encourage family members to have tolerance, realistic perceptions and be able to motivate and encourage family members. This research is library study, which is a data collecting step, examine and analyze data taken from the written literature that is relevant and related to problems that occur in a family. In this study, the focal point is the role of family counseling in overcoming family problems. Therefore, there are various problems that often arise in families and family counseling is one solution that can solve these problems. Meanwhile, this type of data uses primary and secondary data. In addition, the data analysis used reduction technique, presentation and verification and continued checking data for validity. The study results, the Problems that often arise in a family include sexual problems, education, work, inter and inter-family relations, economics, health, and religious issues. These problems are taken from various expert opinions based on family problems. Therefore, family counseling plays a very important role in helping to solve family problems in finding and creating harmonious and balanced psychological conditions so that families become harmonious and happy and families can carry out their functions properly.
\end{abstract}

\begin{tabular}{l}
\hline Keyword: Family problems; family counseling \\
\hline ABSTRAK \\
\hline Pada hakikatnya keluarga adalah wadah yang membentuk dan \\
mempengaruhi kepribadian, sikap dan karakter anak. Dalam \\
membentuk suatu keluarga yang harmonis dan mampu menjalankan \\
tanggung jawab sebagai keluarga bukanlah hal yang mudah, banyak \\
keluarga yang tidak dapat menjalankan fungsi sebagaimana \\
mestinya. Ketidakmampuan keluarga dalam membina hubungan \\
harmoni akan dapat memicu permasalahan dalam keluarga. Oleh \\
karena itu, konseling memberikan solusi yaitu adanya suatu layanan \\
konseling yang bersifat keluarga dalam mencari dan menciptakan \\
kondisi psikologis yang serasi dan seimbang. Konseling keluarga \\
bertujuan untuk membantu anggota keluarga agar mampu bersikap \\
toleransi, persepsi yang realistis, saling menguatkan antar anggota
\end{tabular}




\begin{abstract}
keluarga. Penelitian ini adalah penelitian studi pustaka yaitu serangkaian kegiatan pengumpulan, menelaah dan menganalisa data yang diambil dari literatur-literatur tertulis yang relevan dan berkaitan dengan permasalahan yang terjadi dalam sebuah keluarga. Pengumpulan data diambil melalui data primer dan data sekunder. Tahap analisis data dengan tehnik editing, penjabaran, konfirmasi dan pengecekan kebenaran data. Hasil penjabaran data ditemukan permasalahan paling sering muncul dalam sebuah keluarga diantaranya adalah masalah seksual, pendidikan, pekerjaan, hubungan inter dan antar keluarga, ekonomi, kesehatan, dan masalah agama. Permasalahan tersebut diambil dari berbagai pendapat ahli yang berdasar pada masalah keluarga. Oleh karena itu konseling keluarga sangat berperan untuk membantu penyelesaian permasalahan keluarga dalam mencari dan menciptakan situasi mental yang kondusif dan adaktif sehingga keluarga menjadi harmonis dan bahagia serta keluarga dapat menjalankan fungsi sebagaimana mestinya.
\end{abstract}

Kata kunci: Permasalahan keluarga; konseling keluarga

\title{
PENDAHULUAN
}

Manusia merupakan makhluk "zoon politicon" yang berarti manusia dikodratkan untuk hidup bermasyarakat dan berinteraksi satu sama lain, saling bahu membahu dan juga berorganisasi dengan manusia lainnya guna terpenuhinya kebutuhan hidup mereka (Ihsan, 2002). Dalam artian bahwa hakikatnya manusia bisa memenuhi kebutuhan hidupnya dengan bergotong royong satu sama lain. Allah SWT menjelaskan dalam firman-Nya tentang ciptaan-Nya yang diciptakan secara berpasang-pasangan (laki-laki dan perempuan). Oleh Allah mereka diberi kesempatan untuk sama-sama mengenal, memahami, mengisi, mencari pasangan hidup bahkan untuk membangun rumah tangga sebagai pasangan suami dan istri yang sesuai dengan aturan agama (Islam) dan menurut aturan Negara (Undang-undang) yang dikenal dengan ikatan pernikahan (Marjonet, 2003).

Pernikahan selain sebagai pemersatu antara laki-laki dan perempuan, juga menjadi cara untuk memperoleh keturunan. Dalam pandangan Islam perkawinan memberikan perhatian dan prioritas terhadap institusi keluarga untuk mewujudkan kemuliaan, kehormatan dan amal saleh yang bermanfaat. Sebagaimana Allah SWT berfirman dalam Quran Surat Ar-Ruum: 21 yang berbunyi:

"Dan di antara tanda-tanda kekuasaan-Nya ialah Dia menciptakan untukmu isteriisteri dari jenismu sendiri, supaya kamu cenderung dan merasa tenteram kepadanya, dan dijadikan-Nya diantaramu rasa kasih dan sayang. Sesungguhnya pada yang demikian itu benar-benar terdapat tanda-tanda bagi kaum yang berfikir" (DepagRI, 1998). 
Firman Allah dalam Qs: Ar-Ruum menerangkan dalam pernikahan tidak berarti harus selalu ada ketenteraman, gejolak nafsu dan birahi yang menumpuk, melainkan makna ketenteraman, rahasia kegelisahan dalam diri manusia yang dirasakan sebagai kekosongan yang harus dipenuhi dan kekurangan itu yang harus disempurnakan.

Dalam berkeluarga idealnya adalah kebersamaan suami istri harus berpegang teguh kepada syari'at Islam dan harus ada saling pengertian antara satu dengan yang lain, yang salah satunya adalah antara suami dan istri harus memahami dan mengerti akan kewajiban dan haknya. Kewajiban harus dipenuhi dan hak pantas untuk diterima. Apabila ada salah satu anggota dalam keluarga tidak menjalankan tugas atau kewajibannya atau tidak sesuai fungsinya, maka akan timbul ketidakharmonisan dalam kehidupan rumah tangga/keluarga.

Sebagaimana hal tersebut, ada kalanya dalam keluarga akan muncul berbagai masalah dimana pada umumnya permasalahan yang muncul dalam rumah tangga/keluarga dikarenakan oleh kewajiban dan hak yang tidak dijalankan sebagaimana mestinya oleh pasangan dalam hal ini istri dan suami atau tidak terpenuhinya segala hal yang diinginkan oleh masing-masing pihak. Dalam garis besarnya masalah itu disebabkan oleh rasa bosan, kesibukan, kurangnya perhatian terhadap masalah seks, masalah ekomoni dan sebagainya. Dalam hal ini, berubahnya keadaan diera modern ini masalah dalam keluarga menjadi berubah sifat dan intensitasnya, jumlahnya dan ragamnya. Dimana persoalan dalam keluarga di era modern ini memiliki intensitas yang tinggi terhadap persoalan tersebut. Masalah tersebut adalah adanya masalah ekonomi, kesehatan, seks, pendidikan dan sebagainya. Persoalan-persoalan kecil dan sederhana yang sering menjadi penyebab kesulitan keluarga. Tetapi oleh karena yang kecil dan sederhana tidak mendapatkan penyelesaian atau pemecahan, dan telah datangnya kesulitan yang baru maka akhirnya masalah tersebut akan menjadi masalah yang besar sehingga sulit untuk mengatasinya.

Oleh karena itu, ketidakmampuan keluarga lambat laun akan memicu permasalahan yang akan timbul dalam keluarga baik masalah ekonomi, pekerjaan, pendidikan, kesehatan maupun keyakinan atau agama. Dimana penundaan pemecahan masalah tersebut dalam keluarga sehingga membuat masalah semakin rumit, dan hal tersebut akan menjadi pemicu hancurnya keluarga yang selama ini yang sudah dibinanya. Dengan kata lain, beberapa komponen yang menyebabkan pembinaan dalam kehidupan berkeluarga tidak baik atau tidak seperti yang diharapkan yaitu untuk menjadi keluarga yang sakinah, mawaddah dan warahmah. 
Berdasarkan realita tersebut, bahwa adanya permasalahan yang terjadi dalam kehidupan berumah tangga seringkali tidak bisa diselesaikan oleh kedua belah pihak dengan kepala dingin. Oleh karena itu, diperlukan adanya pelayanan yang profesional untuk membantu mengatasi permasalahan yang dihadapi oleh keluarga. Konseling keluarga pada dasarnya adalah penerapan konseling pada situasi tertentu (Latipun, 2003). Dalam artian, secara khusus mengutamakan pada permasalahan yang berkaitan dengan kondisi keluarga dan penanganannya melibatkan anggota keluarga seperti individu yang menjadi pasangan dalam pernikahan, anak, mertua, saudara maupun pihak lainnya.

\section{METODE}

Penelitian ini merupakan kajian pustaka atau Library Research. Library Research adalah penelitian terhadap beberapa sumber atau literatur baik buku/sumber utama, majalah, buletin, Koran (surat kabar), media elektronik internet, hasil seminar, dan sumber-sumber lainnya yang berkaitan dengan masalah yang dirumuskan (Kartono, 1996). Jadi, penulis akan melakukan serangkaian kegiatan penghimpunan, menelaah dan menguraikan data yang diambil dari literatur-literatur tertulis yang ada relevansi dan kaitannya dengan permasalahan tersebut. Sedangkan dalam penghimpunan datanya, peneliti memakai dua sumber yaitu data primer dan data sekunder (pendukung). Data Primer adalah buku-buku yang berhubungan dengan peran konseling keluarga dalam mengatasi permasalahan keluarga (buku latipun), Bimo yang berjudul Bimbingan dan Konsultasi Perkawinan, Ahmad Mubarok dalam bukunya Konseling Agama (Teori dan Kasus), Sayekti Pujosuwarno dalam bukunya Bimbingan dan Konseling Keluarga, Elida Prayitno dalam mbukunya Psikologi Keluarga, Save Dagun dalam bukunya Psikologi Keluarga dan lain sebagainya.

Sedangkan data pendukung (sekunder) adalah literature-literatur yang sesuai dengan riset ini: Ramlan Mardjoned dalam bukunya Keluarga Sakinah Rumahku Surgaku, M. Quraish Shihab dalam bukunya Wawasan Al- Qur'an, Muhammad Ali dalam bukunya Jati Diri Wanita Muslimah, Departemen Agama dalam bukunya Modul Pembinaan Keluarga Sakinah, Pedoman Konselor Keluarga Sakinah, Khoirudin Bashori dalam bukunya Psikologim Keluarga Sakinah, Ahmad Faiz dalam bukunya Cita Keluarga Islam dan lain sebagainya. 


\section{HASIL DAN BAHASAN}

\section{Permasalahan Dalam Keluarga}

Masalah merupakan point utama dari praktik bimbingan dan konseling. Kegiatan bimbingan dan konseling ada karena individu memiliki masalah, dengan kata lain hal tersebut merupakan organ dari kegiatan bimbingan dan konseling. Dalam hal ini, tujuan dari bimbingan dan konseling adalah untuk mengupayakan pencegahan serta memberikan bantuan dalam memecahkan permasalahan yang dialami oleh individu. Namun, ada kalanya individu akan sangat peka dalam menghadapi masalah walaupun itu sangat ringan tetapi sebaliknya ada juga individu yang sabar dalam menghadapi masalah yang berat dan serius. Akan tetapi, pada umumnya masalah sangat mengganggu kehidupan manusia. Menurut Hornby, A.SCS dalam Pujosuwarno (1994) menyatakan bahwa masalah adalah:

A problem is something that must be overcome and a solution is found.

Dari definisi di atas, masalah merupakan sesuatu yang membutuhkan pemikiran untuk menemukan pemecahannya atau sesuatu yang membutuhkan jawaban dalam menemukan pemecahannya.

Dalam hal ini, terutama pada masalah keluarga ada kalanya disebabkan oleh tindakan ayah, ibu ataupun anaknya serta keadaan lingkungan. Dengan demikian, masalah yang kerap muncul dalam keluarga menurut Sayekti Pujosuwarno, dapat diklasifikasikan sebagai berikut:

\section{Masalah seksual}

Masalah seksual merupakan masalah yang sangat rentan terjadi dalam sebuah keluarga. Oleh karena problematika ini terkait dengan fungsi keluarga sebagai penerus garis keturunan, juga berkaitan dengan tipe keluarga yaitu tipe keluarga besar dan tipe keluarga kecil. Keluarga sebagai penyalur seksual yang syah, antara suami isteri sangat rentan menjalani masalah ini terutama dalam penyalurannya. Permasalahan seksual ini tidak hanya terbatas mengganggu pasangan suami isteri saja, tetapi anak ada kalanya juga mengalami masalah seksual. Misalnya, dilakukan onani atau masturbasi oleh anak. Dalam hal ini, sering kali bersamaan dilakukannya perbuatan tersebut akan diiringi dengan perasaan takut, berdosa dan bersalah, sehingga hal itu akan berdampak negatif terhadap anak yaitu anak sering menjadi murung, kecewa dan putus asa.

2. Masalah kesehatan 
Merupakan salah satunya juga berhubungan dengan masalah seks. Dalam hal ini, faktor kesehatan juga dipandang penting selain faktor seks, menurunnya kesehatan anggota keluarga mengakibatkan terganggunya kesehatan keluarga, sering berobat dan menderita sakit menular dari salah seorang anggota keluarga akan mengurangi dan menghambat tercapainya kesejahteraan keluarga. Masalah kesehatan tidak hanya menyangkut kesehatan jasmani melainkan juga kesehatan rohani serta lingkungan sekitarnya.

\section{Masalah ekonomi}

Masalah ini juga menjadi masalah yang kerap timbul di sebuah rumah tangga. Ketika keadaan ekonomi sedang lemah sangat mencemaskan bagi kehidupan keluarga. Oleh karena tidak semua keluarga beruntung untuk dapat memperoleh penghasilan yang mencukupi. Ayah adalah seorang kepala keluarga sekaligus menjadi pencari nafkah untuk menunjang keadaan ekonomi dalam rumahtangga. Oleh karena itu, tanggung jawabnya adalah memberi nafkah dalam keluarga. Nafkah adalah "semua kebutuhan dan keperluan yang berlaku menurut keadaan dan tempat, seperti makanan, pakaian, rumah dan sebagainya” (Rasyid, 1994). Pada dasarnya kesulitan ekonomi keluarga adalah salah satu penyebab timbulnya problematika bagi pasangan suami istri bahkan berdampak terhadap anak maupun anggota keluarga yang lain. Misalnya dalam menghadapi kesulitan ekonomi tersebut terkadang hal yang ditampilkan adalah sikap reaktif dan emosional. Dalam artian, sikap yang ditampilkan tersebut adalah terperangkap dalam tekanan psikologis dan tidak mampu memotivasi diri.

\section{Masalah pendidikan}

Menurut pandangan Islam pendidikan merupakan langkah terbaik bagi manusia dalam menjalankan fungsi dan fitrahnya sebagai khalifah Allah. Oleh karena itu, manusia memiliki potensi akal pikiran dan kecerdasan. Keluarga adalah kelompok kecil yang terdiri dari ayah, ibu dan anak-anak yang berada di tengah masyarakat, tempat anak tumbuh dan berkembang, pembentukan karakter, emosi dan kepribadian, mendapatkan pendidikan, perlindungan dan keamanan, sesuai dengan pola asuh orangtua sebelum anak terjun ke lingkungan masyarakat. Peran orang tua dalam mendidik tentu harus memperhatikan potensi yang dimiliki anak. Dalam mendidik, dilakukan dengan cara membimbing, membantu/mengarahkan agar ia mengenal norma dan tujuan hidup yang hendak dicapainya. Peran orang tua dalam mendidik anak penting dilakukan, untuk membimbing dan membina keberagaman anak, sehingga kelak mereka mampu melaksanakan kehidupan sebagai anggota keluarga dan anggota masyarakat serta taat terhadap agama yang dipeluknya (Warsah, 2020). 
5. Masalah pekerjaan

Masalah pekerjaan merupakan masalah dalam keluarga yang menyangkut didalamnya tentang kebutuhan dalam menjalani kehidupan. Dalam sebuah keluarga terutama keluarga inti, bahwa bagi tipe keluarga besar terkadang dalam memenuhi kebutuhannya yaitu dengan berjuang secara kerja keras. Akan tetapi, dalam pemenuhan kebutuhan tersebut berdampak yaitu tidak adanya hubungan kasih sayang dalam keluarga. Misalnya, suami dalam kehidupan rumah tangga adalah seorang yang bertanggung jawab dalam mencari nafkah. Oleh karena tuntutan dalam pemenuhan kebutuhan tersebut, maka suami menerapkan kesibukan. Dengan kondisi tersebut, akan berdampak negatif baik pada isteri maupun anak. 6. Masalah Hubungan Interpersonal dalam Keluarga

Hubungan Interpersonal dan Fungsi keluarga dibentuk oleh anggota keluarga melalui interaksi secara berkelanjutan. Interaksi keluarga adalah respon anggota keluarga terhadap tindakan atau tingkah laku anggota keluarga lainnya. Interaksi keluarga merupakan keseluruhan perasaan yang ditampilkan anggota keluarga. Peran setiap anggota keluarga dalam keluarga secara langsung berkaitan dengan perasaan yang dimainkan oleh anggota keluarga Peran keluarga berasal dari posisi norma, peran dan tingkahlaku peran (Prayitno, 2004). Peran setiap orang dalam keluarga bisa saling berinteraksi antara satu dengan yang lain. Oleh karena peran anggota keluarga adalah bagian dari posisi sosial yang mereka tempati dengan keluarga.

\section{Masalah agama}

Masalah agama merupakan masalah yang terkadang menyulitkan dalam membina kehidupan berumah tangga. Dalam hal ini, perkawinan antara pasangan yang beda agama memiliki kecenderungan rawan konflik bila dibandingkan dengan perkawinan yang seagama yang dapat berujung pada perceraian. Seiring dengan itu, pasangan yang beda agama menimbulkan dampak negatif bagi perkembangan anak, hal ini menyebabkan kebingungan bagi anak terutama dalam menentukan kepercayaan yang akan dianutnya. Latipun mengemukakan bahwa masalah yang kerap muncul dalam sebuah keluarga adalah adanya anggota keluarga mengalami kondisi yang kurang harmoni di dalam keluarga akibat stresor perubahan-perubahan budaya, cara - cara baru dalam mengatur keluarganya, dan cara menghadapi dan mendidik anak-anaknya. Misalnya adanya ketidakharmonisan dalam keluarga salah satunya adalah keluarga dengan anak yang tidak mengikuti keinginan orang 
tua, adanya masalah sesama anggota keluarga, perpisahan diantara anggota keluarga karena kerja di luar daerah dan anak yang menderita gangguan kesulitan belajar atau hubungan sosial (Latipun, 2003).

\section{Peran Konseling Keluarga Dalam Mengatasi Permasalahan Keluarga}

Keluarga merupakan tempat pertama pertumbuhan anak. Tentu pertumbuhan dan perkembangan perilaku dan kepribadian anak sangat dipengaruhi oleh pola pendidikan anak dalam keluarga, terutama pada periode pertama dalam kehidupannya sebagai masa pembentukan karakter. Pada masa tersebut perilaku anggota keluarga sangat berpengaruh dalam pembentukan karakter anak dan berimplikasi pada karakter mereka mendatang (Warsah, 2020). Didalam keluarga peran orang tua sangat penting bagi anak, orang tua adalah kontak sosial yang paing awal dan yang paling kuat. Akibatnya, orangtua menjadi sangat penting di mata anak. Apa yang dikomunikaskan oleh orang tua pada anak lebih menancap daripada infrormasi lain yang diterima anak sepanjang hidupnya. Bagaimanapun perlakuan orang ttua terhadap anak, anak meduga bahwa dirinya memang pantas diperlakukan begitu (Fadila \& Hartini, 2017).

Keluarga pada hakikatnya adalah wadah yang membentuk dan mempengaruhi kepribadian, sikap dan karakter anak. Seorang anak yang dilahirkan dan dibentuk dalam sebuah lingkungan keluarga yang harmonis dan mampu menjalankan fungsi-fungsi utama keluarga. Akan membuat anak merasakan betapa pentingnya keluarga dalam kehidupannya. Akan tetapi, untuk membentuk suatu keluarga yang harmonis dan mampu menjalankan tanggung jawab sebagai keluarga bukanlah hal yang mudah, banyak keluarga yang tidak dapat menjalankan fungsi sebagaimana mestinya. Ketidakmampuan keluarga ini akan dapat memicu permasalahan dalam keluarga yang salah satunya adalah perceraian. Perceraian adalah berakhirnya suatu pernikahan yang disebabkan oleh kegagalan dalam menjalankan obligasi peran dalam pernikahan (Prayitno, 2005).

Perceraian keluarga tidak terjadi begitu saja tanpa sebab yang jelas. Tanpa ada sebab tidak akan mungkin pernikahan yang dalam Al-Qur'an disebut ikatan yang kokoh akan diakhiri dengan perceraian. Bahkan dalam islam perceraian itu baru boleh dilakukan apabila ada sebab-sebab yang dibenarkan oleh syara'. Dalam hal ini perceraian tidak selalu disebabkan oleh satu peristiwa yang sama bagi setiap pasangan yang melakukan perceraian.

Ketidakmampuan keluarga dalam membina hubungan harmoni akan dapat memicu permasalahan dalam keluarga yang salah satunya adalah perceraian. Berdasarkan permasalahan yang kerap muncul dalam keluarga salah satunya adalah perceraian seperti 
yang tersebut diatas, maka untuk membantu penyelesaian permasalahan tersebut, konseling memberikan solusi yaitu dengan adanya suatu layanan konseling yang bersifat keluarga dalam mencari dan menciptakan kondisi psikologis yang serasi dan seimbang sehingga keluarga menjadi harmonis dan bahagia serta dapat menjalankan fungsi sebagaimana mestinya yaitu melalui konseling keluarga (Family Counseling).

Menurut Pujosuwarno (1994), bahwa peran konseling keluarga adalah membantu anggota keluarga agar mampu bersikap toleransi, persepsi yang realistis, saling menguatkan antar anggota keluarga Dengan kata lain, bahwa adanya konseling keluarga dapat membantu anggota keluarga untuk saling memahami serta mengembangkan rasa penghargaan dari seluruh anggota keluarga pada anggota yang lain.

Sedangkan menurut Latipun, mengemukakan bahwa peran konseling keluarga adalah menyokong anggota keluarga untuk mencapai keistimewaan dirinya, menjadi dirinya sebagai hal yang berbeda dari sistem keluarga (Latipun, 2003).

Seiring dengan hal tersebut, Elida Prayitno mengemukakan bahwa peran konseling keluarga adalah:

1. Membina cara mengambil keputusan yang rasional.

Membina kondisi berfikir yang rasional dalam memahami tingkah laku sendiri dan akibatnya kepada hubungannya dengan pasangan dan mengambil keputusan untuk memecahkan masalah keluarga. Apabila dalam keluarga masing - masing anggota pasangan mengambil keputusan yang tidak rasional, maka bantuan konselor diperlukan untuk menciptakan pengambilan keputusan yang rasional. Dalam hal ini permasalahan yang kerap terjadi dalam keluarga adalah masalah latar pendidikan orang tua yang akan diberikan kepada anak. Oleh karena pendidikan sangat penting dalam membentuk kepribadian anak maka orang tua harus dapat memahami peran masing -masing. Jika hal tersebut terjadi sebaliknya pendekatan yang dapat konselor berikan adalah dengan menggunakan pendekatan sistem keluarga. Adanya pendekatan ini bertujuan untuk antara suami istri tidak dapat membebaskan dirinya dari peran masing - masing. Prosedur yang digunakan oleh konselor adalah dengan mengidentifikasi masalah yang dihadapi oleh klien agar teknik yang diberikan sesuai dengan kondisi permasalahan yang dihadapi oleh klien. Dalam artian konselor diharapkan dapat membantu masing - masing anggota keluarga agara menyadari penyimpangan tingkah laku, kematangan kepribadian yang belum dicapai, dan perlunya pemulihannya dalam menciptakan keluarga yang harmonis. Oleh karena itu, jika konseling 
dapat berjalan dengan sukses dapat membantu memperbaiki tingkah laku keluarga yang rasional dan mengambil keputusan yan rasional juga.

2. Memberikan pelatihan

Konseling keluarga berfungsi untuk melatih pasangan pernikahan melakukan teknik dan cara mengatasi permasalahan, seperti teknik dan cara berinteraksi dengan pasangan atau teknik pengambilan keputusan. Dalam hal ini keterkaitan permasalahan yang dialami adalah kurang harmonisnya hubungan inter dan antar anggota keluarga salah satunya adalah masalah komunikasi. Dalam keluarga ada kemungkunan terdapat beberapa pola komunikasi diantaranya dengan pola kesamaan (Equality) yang berarti antara suami isteri mempunyai kedudukan yang seimbang, tetapi ada kemungkinan terdapat pola komunikasi yang lainnya yaitu pola komunikasi yang masih ada keseimbangan antara suami istri tetapi masing masing pihak mempunyai otoritas dalam bidang tertentu. Misalnya suami memiliki kredibilitas yang tinggi dalam hal politik, sedangkan istri mempunyai kredibilitas yang tinggi dalam hal ilmu. Permasalahan tersebut dapat diadakannya pemecahannya melalui konseling keluarga yaitu seorang konselor memberikan pendekatan yaitu pendekatan conjoint, yang bertujuan untuk membantu anggota keluarga mampu secara keseluruhan untuk permasalahan yang dihadapi dikomunikasikan kepada anggota keluarga yang lainnya.

\section{Mediasi}

Teknik mediasai menjadi penengah, dalam artian bahwa konselor dapat memberikan nasehat dengan alasan - alasan yang rasional agar pasangan memiliki kepribadian yang sehat (Prayitno, 2005). Permasalahan yang kerap terjadi adalah salah satunya masalah perceraian, misalnya faktor yang melatarbelakangi terjadinya perceraian tersebut dikarenakan adanya kekerasan dalam rumah tangga. Kekerasan dalam rumah rtangga adalah Perbuatan (sikap /sifat) seseorang ataupun kelompok berupa ancaman, paksaan, penganiayaan di dalam suatu rumah tangga yang menyebabkan cedera fisik maupun psikis bahkan dapat menyebabkan kematian.

Dalam melaksanakan konseling keluarga terdapat prosedur yang dilakukan konselor sesuai dengan kebutuhan. Ada beberapa tahapan-tahapan yang dapat dilakukan oleh konselor untuk membantu mengentaskan permasalahan seperti yang tersebut diatas yaitu antara lain:

1. Tahap Awal, yaitu tahap yang dilakukan klien menghubungi konselor. Dalam artian bahwa pada tahap ini klien ada kesepakatan dengan konselor dalam melakukan proses 
konseling. Dalam tahap ini klien ada yang datang secara sukarela kepada konselor dan ada yang datang tidak sukarela karena adanya dorongan dari orang lain.

2. Tahap Keterlibatan, yaitu tahap keikutsertaan klien. Pada tahap ini konselor mulai mengikutsertakan klien secara verbal dan non verbal. Dalam artian bahwa, tahap ini konselor melakukan refleksi perasaan dengan memberikan penjelasan dan sebagainya terhadap klien.

3. Tahap Pemahaman Masalah, yaitu tahap menetpakan masalah yang dialami oleh klien. Dalam hal ini, konselor harus jelas dan tepat dalam menetapkan apa masalahnya, siapa yang bermasalah, apa indikasinya terhadap apa-apa yang dikemukakan oleh klien.

4. Tahap Menghubungkan, yaitu tahap konselor menentukankan pola hubungan dalam menyelesaikan permasalahannya. Pada fase ini anggota keluarga akan menemukan data yang diperlukan untuk pemecahan masalahnya dan konselor dapat membina anggota keluarga itu berinteraksi dengan cara - cara yang dapat diikuti dalam kehidupan keluarga.

5. Tahap Pertemuan, yaitu tahap menyusun hipotesis dan merumuskan langkah-langkah pemecahan. Pada tahap ini konselor membuat pola langsung atau memberi tugas yang telah disusun untuk diterapkan langsung untuk menyelesaikan masalah dalam perkawinan.

6. Tahap Penentuan Tujuan, yaitu tahap keberhasilan usaha klien untuk kembali ke tingkah laku yang normal. Dalam artian bahwa klien dapat merelisasikan yang brerkaitan dengan permasalahan yang dihadapinya, misalnya klien berusaha membangun komunikasi efektif, mengoptimalkan harga diri dan dapat membuat keluarga lebih saling ketergantungan.

7. Tahap Akhir, yaitu tahap dimana setelah tercapainya tujuan konseling, maka di perlukannya proses pengakhiran hubungan konseling (Latipun, 2005).

Dalam prosedur konseling keluarga sesuai dengan langkah-langkah konseling tersebut sangat diperlukan pendekatan-pendekatan serta metode dan teknik- teknik konseling. Bahwa mengenai pendekatan, metode dan teknik dalam konseling keluarga pada dasarnya sama dengan konseling pada umumnya. Hanya saja perbedaan tersebut terletak dalam prakteknya yang berkemungkinan memerlukan teknik - teknik tersendiri sesuai dengan permasalahannya. Oleh karena itu, sangat dibutuhkan seorang konselor yang profesional dalam membantu klien. Adapun peranan konselor yang dikemukakan oleh Satir adalah sebagai berikut: 
1. Konselor berfungsi sebagai "Facilitative a Comportable" membimbing klien melihat secara jelas dan objektif dirinya dan tindakan-tindakannya sendiri. Hubungan antara konselor dengan klien merupakan salah satu aspek yang penting dalam konseling. Dimana konselor yang efektif adalah mereka yang dapat menciptakan hubungan yang bersifat membantu dan tanpa tekanan dengan kliennya, sehingga konselor dan klien itu sama-sama dapat merasa tentram dan aman untuk saling berhubungan secara bebas dan spontan. Dalam artian bahwa konselor sebaiknya dapat memberikan rasa nyaman selama proses konseling berlangsung. Sehingga klien dengan secara sukarela untuk terbuka terhadap permasalahan yang dialaminya. Mengamati kondisi tersebut akan dapat membantu klien melihat secara jelas dan objektif dirinya dan tindakan - tindakan sendiri. Oleh karena itu, konselor dalam melaksanakan konseling dapat menggunakan teknik sesuai dengan kebutuhan dan permmasalahan yang sedang dihadapinya.

2. Konselor memakai perlakuan/Treatmen melalui latar belakang hubungan.

Bahwa latar belakang hubungan dapat digunakan sesuai dengan kebutuhan serta permasalahan klien. Misalnya, permasalahan antara suami istri dalam hal mendidik anak seringkali terjadi karena latar belakang pendidikan orang tuanya. Adanya kondisi tersebut, konselor dapat memberikan perlakuan kepada klien salah satunya dengan menggunakan teknik konseling yaitu memainkan peran serta teknik yang signifikan dengan hal tersebut.

3. Mencoba meniadakan pembelaan diri dan keluarga. Bahwa konselor berupaya untuk membantu klien mengontrol terutama yang berkaitan dengan mekanisme pertahanan diri yaitu dengan cara meniadakan pembelaan diri dan keluarga sesuai permasalahan yang di hadapi oleh klien.

4. Mendidik klien untuk bersikap dewasa dan bertanggungjawab serta melakukan self control. Dalam proses pembelajaran ini merupakan kerja dan tanggung jawab konselor keluarga yang bertujuan untuk membantu klien mengurangi ketegangan dalam dirinya dan dalam hubungannya antara anggota keluarga lainnya yaitu dengan melakukan self control.

5. Konselor menjadi perantara dari perbedaan / jarak komunikasi dan memahami peran-peran yang diutarakan klien / anggota keluarga. Bahwa dalam melaksanakan konseling diharapkan konselor tidak berpihak, dalam artian konselor harus profesional untuk memahami peran tersebut sesuai dengan permasalahannya. Misalnya, terjadi komunikasi dalam keluarga yang tidak berjalan efektif disamping 
karena ada unsur ketakutan untuk mengungkapkan masalahnya. Oleh karena itu, konselor dalam membantu klien tersebut salah satu teknik yang dapat digunakan oleh konselor adalah teknik kursi kosong.

6. Konselor tidak membuat penilaian dan membantu menjadi congruence dalam respon-respon anggota keluarga (Latipun, 2005). Kongruensi (congruence) dalam hubungan konseling adalah "menunjukkan diri sendiri" yang apa adanya dan yang sebenarnya, berpenampilan jujur, serta apa yang diucapkan dan apa yang ditunjukkankan mempunyai kesesuaian. Kesesuaian ini sangat penting dilakukan oleh konselor untuk melawan kebohongan. Dan jika klien mengetahui bahwa konselornya tidak mencerminkan kejujuran, kejelasan, dan keterbukaan dapat memudarkan dan bahkan menghilangkan kepercayaan klien kepada konselor. Kongruensi konselor ini dapat menumbuhkan kepercayaan klien kepada konselor. Dalam artian bahwa selama proses konseling berlangsung konselor dalam kondisi kongruensi diharapkan dapat menimbulkan kongruensi kepada klien. Adanya sikap konselor yang kongruensi dapat menjadi model bagi klien, bahwa dirinya juga harus menunjukkan sikap yang kongruensi tidak hanya di depan konselor melainkan juga setelah hubungan konseling berakhir.

7. Dalam proses pelaksanaan konseling keluarga konselor harus mempertimbangkan berbagai norma dan prosedur baik kepada anak maupun orangtua. Dan konselor juga harus menguasai pemahaman etnis yang berbeda karena keragaman etnis, gender, latar belakang budaya, geografis, asal daerah, ras, kondisi fisik, usia, serta keragaman sosial ekonomi, agama, karakteristik pribadi, kemampuan sosial, perilaku dan kebiasaan serta kemampuan intelektual, telah menjadi fenomena keseharian, yang diakibatkan oleh penyebaran penduduk, mengikuti pekerjaan orang tua, atau perpindahan untuk mendapatkan pendidikan ditempat yang berbeda budaya. Dengan pemahaman tersebut konselor dapat menganalisa berbagai permasalahan yang di hadapi di setiap anggota keluarga sehingga dapat merancang secara kreatif dan dinamis proses konseling (Hartini, 2018).

Konselor memiliki empati dan kepekaan budaya, tidak menggunakan pendekatan atau keterampilan yang bersifat otomatis, memiliki pandangan mendalam, tidak mudah mengelabuhi atau menipu, memiliki pengetahuan diri (self knowledge) dan kesadaran diri (self awareness) secara menyeluruh, belajar dari kesalahan-kesalahan, siap melakukan penataan ulang konteks budaya, memahami kerangka masalah secara tepat, memiliki toleransi tinggi dan terbuka, serta ahli dalam melakukan transendensi diri (Hartini, 2018). 


\section{KESIMPULAN}

Dari uraian pembahasan tentang Peran Konseling Keluarga Dalam Mengatasi Permasalahan Keluarga dapat disimpulkan sebagai berikut: 1) Permasalahan keluarga sangat rentan dan kompleksitas terjadi dalam keluarga adalah masalah seksualitas, pendidikan, ekonomi, komunikasi dan 2) Peran Konseling keluarga Dalam Mengatasi Permasalahan Keluarga, adalah diantaranya: a) Memotivasi anggota keluarga belajar dan memahami bahwa dinamika keluarga merupakan hasil pengaruh hubungan sesama anggota keluarga; b) Memotivasi anggota keluarga agar dapat menerima kenyataan bahwa pandangan, harapan maupun interaksi dengan anggota keluarga lain dapat memberikan pengaruh kepada salah satu anggota keluarga yang sedang mengalami masalah; c) Keseimbangan dalam kehidupan berumah tangga bisa tumbuh dan berkembang dengan upaya melaksanakan konseling keluarga kepada anggota keluarga; d) Mengoptimalkan kapasitas diri dari seluruh anggota keluarga kepada anggota keluarga yang lain; dan e) Memotivasi anggota keluarga mendapatkan kesehatan fisik agar fungsi keluarga jadi maksimal..

\section{DAFTAR RUJUKAN}

Departemen Agama RI. (1998). Al-Qur'an dan Terjemahannya, Jakarta: Mahkota Surabaya.

Fadila dan Hartini. (2017). Konsep Diri Anak Jalanan di Kabupaten Rejang Lebong. Jurnal Fokus Konseling, 3(1), 67-77.

Hartini. (2018). Multicultural Considerations In Group Playtherapy. Paper presented at Seminar Nasional BK Perguruan Tinggi, UPI, Bandung, 6 April 2018 (pp. 197-210). Bandung: UPT-BKPK.

Ihsan, H. (2002). Filsafat Islam. Bandung: Pustaka Setia.

Kartono, K. (1996). Pengantar Metodologi Riset Sosial. Bandung: Mandar Maju.

Latipun. (2003). Psikologi Konseling, Malang: UMM Press.

Marjonet, R. (2003). Keluarga Sakinah Rumahku Surgaku. Jakarta: Media Dakwah.

Prayitno, E. (2005). Konseling Keluarga. Padang: UNP.

Prayitno. (2004). Dasar-Dasar Bimbingan dan Konseling. Jakarta: Rineka Cipta.

Pujosuwarno, S. (1994). Bimbingan dan Konseling Keluarga. Yogyakarta: Menara Mas Offset.

Rasyid, S. (1994). Fiqih Islam. Jakarta: Sinar Baru Aksindo.

Warsah, I. (2020) Pendidikan Islam Dalam Keluarga. Palembang: Tunas Gemilang Press. 